\title{
«Le Moyen Français» 64, 2009
}

\section{Paola Cifarelli}

\section{(2) OpenEdition}

\section{Journals}

\section{Édition électronique}

URL : http://journals.openedition.org/studifrancesi/5888

DOI : 10.4000/studifrancesi.5888

ISSN : 2427-5856

\section{Éditeur}

Rosenberg \& Sellier

\section{Édition imprimée}

Date de publication : 1 mai 2011

Pagination : 154

ISSN : 0039-2944

\section{Référence électronique}

Paola Cifarelli, « «Le Moyen Français» 64, 2009 », Studi Francesi [En ligne], 163 (LV | I) | 2011, mis en ligne le 30 novembre 2015, consulté le 11 janvier 2021. URL : http://journals.openedition.org/ studifrancesi/5888 ; DOI : https://doi.org/10.4000/studifrancesi.5888

\section{Ce document a été généré automatiquement le 11 janvier 2021.}

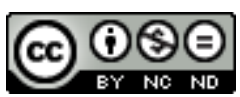

Studi Francesi è distribuita con Licenza Creative Commons Attribuzione - Non commerciale - Non opere derivate 4.0 Internazionale. 


\section{«Le Moyen Français» 64, 2009}

\section{Paola Cifarelli}

\section{RÉFÉRENCE}

«Le Moyen Français» 64, 2009.

1 Maria colombo timelli, La «Tresplaisante et recreative hystoire du trespreulx et vaillant chevallier Perceval le Galloys...» (1530), mise en prose tardive du 'cycle du Graal', pp. 13-54; l'A. analyse la mise en prose du Conte du Graal parue à Paris en 1530 et ses rapports avec la tradition manuscrite du modèle en vers qui nous est parvenue. Après un examen détaillé des textes liminaires, l'A. prend en compte l'organisation de la matière et son découpage; mais plutôt que cet aspect, ce qui s'est révélé intéressant pour identifier des rapports privilégiés du dérimage avec quelques-uns des manuscrits conservés, c'est l'analyse des variantes. Grâce aux sondages opérés sur le texte, les deux témoins $T$ et $U$ - et non pas $E$ - se révèlent comme les plus proches de la version en prose, malgré le caractère lacunaire de la tradition et la variation des rapports d'un manuscrit à l'autre $\mathrm{du}$ cycle. Deux annexes contiennent respectivement la transcription de l'apparat péritextuel et celle des titres-sommaires qui servent à introduire les différents chapitres.

2 Alain CORBELLARI (À la place du mort. Une lecture politique de "La belle Dame sans Mercy", pp. 55-66) aborde le seul texte d'Alain Chartier qui, apparemment, ne s'engage pas dans la réalité douloureuse de la Guerre de Cent Ans; l'A. propose de le lire aussi comme une allégorie de la France. La dernière strophe du poème, ainsi que quelques détails dans le texte (l'adjectif féminin france sans palatalisation entre autres) permettent d'établir des parallèles avec le Quadriloge invectif et de mettre en évidence une portée politique de la Belle Dame sans Mercy, renforcée par le statut du narrateur.

3 Rebecca DIXON (Allégorie et construction de mythes chez Michault Taillevent: le "Songe de la Toison d'Or", pp. 67-84) soumet le poème allégorique de Taillevent sur la fondation de l'Ordre de la Toison d'Or à une lecture qui en met en valeur le contenu idéologique, 
mais qui insiste également sur l'importance de la poésie et de sa maîtrise technique pour la construction de la renommée.

4 Claudio GALDERISI ('Lectio philologica', 'lectio poetica' et 'lectio pigra'. Variantes poétiques et philologie d'auteur dans trois poèmes de Charles d'Orléans, pp. 85-110) soulève d'intéressantes questions à propos de la réception de l'œuvre médiévale et du rôle de la philologie comme intermédiaire indispensable entre le texte ancien et le lecteur moderne, en prenant parti dans un débat sur la spécificité des critères ecdotiques à adopter pour les œuvres du Moyen Âge tardif. Selon l'A., les notions de variance et de mouvance, examinées sous l'angle des variantes d'auteur, sont porteuses de précieuses informations littéraires et poétiques. L'observatoire privilégié pour cette enquête est celui des poèmes de Charles d'Orléans. 